\title{
Aplikasi Rekomendasi Resep Masakan Khas Indonesia bagian Timur Menggunakan Metode Collaboration Collective Intelligence dan Slope One
}

\author{
${ }^{1}$ Rendra Soekarta, ${ }^{2}$ Mersi Modok \\ ${ }^{12}$ Universitas Muhammadiyah Sorong
}

Email: rendrasoq@um-sorong.ac.id, mersimodok@gmail.com

\begin{abstract}
Food recipes are important in the composition of dishes, and also not only physically but some are needed digital. So users don't need to save recipe books which has been purchased to find recipes. From websites that provide recommendations for digital recipe guide is dapurSiapsaji. This application helps users to search for recipes just by entering ingredients from food that is owned by the user. And it will produce a list of menus or in other words a list of dishes using previously entered ingredients users. And there are also related recommendations after opening one of the recipes after the search. Not only that, this website can also provide freedom for innovate, by the way all users can fill in new recipes according to innovation and creation itself. Then the recipe will be published and read by the public. Collective Collective Intelligence and Slope One the method is implemented in the design of this application design.
\end{abstract}

Keywords

Recipe, Collective Collaborative Intelligence, Dish, slope one

\begin{abstract}
Abstrak
Resep makanan penting dalam komposisi hidangan, dan juga tidak hanya secara fisik tetapi beberapa dibutuhkan digital. Jadi pengguna tidak perlu menyimpan buku resep yang telah dibeli untuk menemukan resep. Dari situs web yang memberikan rekomendasi untuk digital panduan resep adalah dapurSiapsaji. Aplikasi ini membantu pengguna untuk mencari resep hanya dengan memasukkan bahan dari makanan yang dimiliki oleh pengguna. Dan itu akan menghasilkan daftar menu atau dengan kata lain daftar hidangan menggunakan bahan yang dimasukkan sebelumnya pengguna. Dan ada juga rekomendasi terkait setelah membuka salah satu resep setelah pencarian. Tidak hanya itu, situs web ini juga dapat memberikan kebebasan untuk berinovasi, dengan cara semua pengguna dapat mengisi resep baru sesuai dengan inovasi dan kreasi itu sendiri. Kemudian resepnya akan dipublikasikan dan dibaca oleh publik. Kolektif Kecerdasan Kolektif dan Kemiringan Satu metode ini diimplementasikan dalam desain desain aplikasi ini.
\end{abstract}

Kata kunci

Resep, Kolaborasi Kolektif Kecerdasan, hidangan, kemiringan satu

\section{Pendahuluan}

Makanan merupakan hal penting yang sangat dibutuhkan setiap manusia, karena makanan mencakup berbagai nutrisi penting seperti lemak,protein, karbohidrat, mineral,Vitamin dan lain sebagainya.selain itu ada juga beberapa zat yang ditambahkan ke makanan baik disengaja maupun tidak disengaja yang akan mempengaruhi kualitas makanan itu sendiri. Bahan tambahan seperti zat aditif yang bersifat sintetis dapat membahayakan bagi siapapun yang mengkonsumsinya.

Dalam kehidupan sehari-hari merupakan hal yang sangat penting dan harus diperhatikan karena konsep personal hygiene akan mempengaruhi kesehatan seseorang dan kebersihan itu sendiri sangat dipengaruhi oleh nilai individu dan 
kebiasaan. Hal-hal yang sangat berpengaruh itu diantaranya kebudayaan, sosial, keluarga, pendidikan, persepsi seseorang terhadap kesehatan.

\section{Kerangka Teori}

\section{a. System Rekomendasi}

Sistem rekomendasi merupakan sistem yang digunakan untuk membantu pengguna dalam memilih keputusan. Sistem rekomendasi memerlukan model rekomendasi yang tepat agar apa yang direkomendasikan sesuai dengan keinginan pengguna, serta mempermudah mengambil keputusan yang tepat dalam menentukan suatu keputusan yang akan dilakukan.Dalam mengambil keputusan jika banyak orang dalam sekelompok tidak lain hal ini sangat membantu.

Perekomendasi adalah suatu sistem yang dapat memberikan saran kepada user tentang item yang akan mereka pilih. Rekomendasi dibuat oleh system yang dapat mengarahkan user dalam mendapatkan informasi berupa deskripsi item atau hal yang lain. Sistem rekomendasi telah menjadi hal yang sangat penting untuk diteliti semenjak sangat banyak sekali industri dan juga pendidikan yang mengembangkan sistem ini dan juga dalam pengembangan system penjualan.

\section{b. Collective Intelligence}

Collective Intelligence merupakan kemampuan dari sebuah kelompok atau pun grup untuk mencari solusi masalah yang kompleks dibandingkan harus diselesaikan sendiri. Masalah yang ditimbulkan dapat berasal dari diri sendiri maupun dari luar yang berbeda-beda tingkatanya. Untuk maka diperlukan system ini untuk menunjang perancangan desain ini.

Kecerdasan ini adalah bentuk individu merupakan kemampuan umum kelompok untuk melakukan berbagai tugas. Fenomena ini terkait erat dengan kumpulan peneliti, yang berarti kolektif dan bersatu, perilaku yang besar dan terorganisir dalam mencari suatu kecerdasan kolektif.

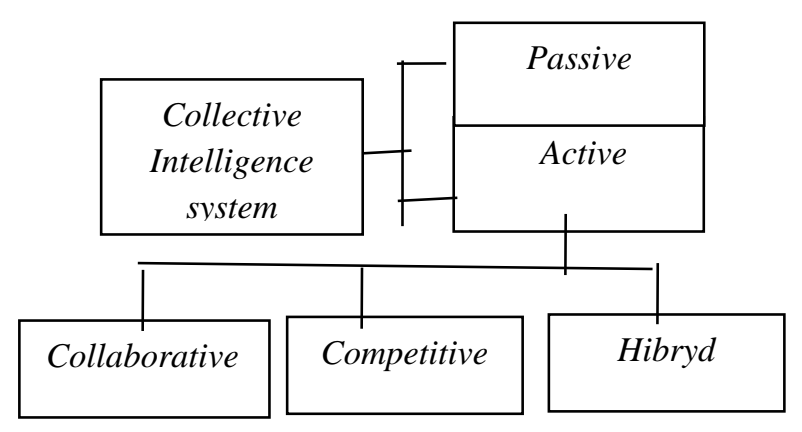

Gambar 1. Klasifikasi dari Sistem Collective Intelligence

c. Slope One Algoritma

Algoritma Slope One terdiri dari tiga jenis, yaitu algoritma Slope One, weighted Slope One, dan bi-polar Slope One. Kelebihan dari algoritma Slope One adalah mudah untuk diimplementasikan, mudah dilakukan update, dan waktu query yang efisien. Algoritma Slope One menghitung rata-rata dari selisih perbedaan rating antara item-item yang sebelumnya sudah dirating oleh pengguna. Lemire juga mengatakan bahwa Algoritma Slope One ini dapat digunakan untuk memprediksi rating item lain berdasarkan item lainnya dimana item tersebut memiliki sebuah relasi dengan mencocokkan perbandingan diantara dua rating objek. Pada setiap objek dibaca dengan teliti berdasar algorimanya.

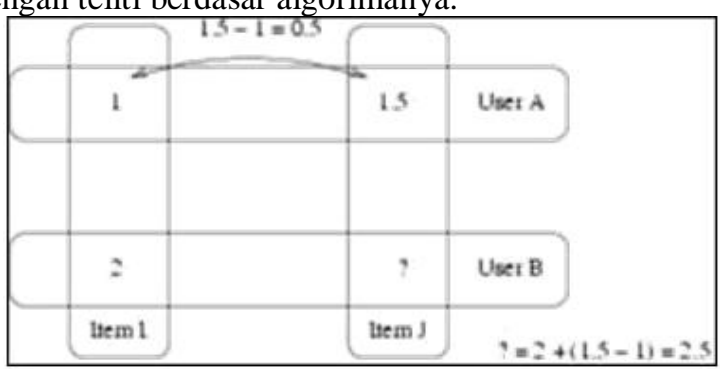

Gambar 2. Contoh penggunaan Algoritma Slope One

Penjelasan:

User A memberikan rating 1 pada item pertama

dan 1.5 pada item kedua

User B memberikan rating 2 pada item pertama.

\section{d. Resep Makanan}

Resep masakan adalah keterangan tentang bahan dan cara memasak makanan.Resep juga dapat diartikan sebagai sekumpulan intruksiintruksi kerja yang berisikan petunjuk untuk membuat suatu masakan ataupun hidangan. Resep memberi petunjuk dan arahan secara detail dan 
tepat pada tiap tahapannya agar pembaca dapat melakukan hal yang sama seperti yang diinstruksikan. Dengan kita mengetahui resep makanan yang akan kita konsumsi maka akan baik baik juga memaju selerah makan seseorang.

\section{Metode dan Perancangan}

a) Metode Penelitian

1. Study literature

Peneliti akan mencari dan mempelajari bahan yang berkaitan dengan metode penelitian dari berbagai buku dan jurnal referensi serta mensearching secara online yg berhubungan dengan metode yang telah peneliti rancangkan.

2. Analisis System

Analisis memperhatikan kebutuhankebutuhan yang diperlukan dalam pembangunan sistem, seperti platform yang digunakan untuk implementasi sistem, dengan mempelajari banyak hal yang mengenai keluhan yang di dapat.

3. Implementasi Implementasi Collective Intelligence dalam pembuatan aplikasi dan fitur apa saja yang perlu disediakan untuk mempermudah pengguna saat menggunakan aplikasi. Pada tahapan ini juga dilakukan perancangan User Interface yang memberikan navigasi kepada user sehingga user akan mengerti maksud dan tujuan pada tiap-tiap tombol pada aplikasi. Dan juga akan ada database untuk menyimpan data masakan, data diri user dan data inputan user yang telah diterima berdasarkan inputan dari user itu sendiri. Perlunya di implementasi untuk memudahkan pengguna dan jugan pengaplikasian peneliti.

4. Pemrograman system

Pemrograman untuk aplikasi ini dengan menggunakan ATOM dengan bahasa PHP, WEBSITE ,HTML dan DATABASE yang menggunakan MYSQL. Pada perancangan aplikasi ini di terapkan seperti hal diatas.

5. Evaluasi dan Uji Coba

Uji Coba terhadap aplikasi akan mencari beberapa teman untuk berperan sebagai pengguna. Diharapkan jika dalam pengujian system ada feedback yang berupa kepuasan user berdasarkan rating user dan juga saran user yang didapatkan melalui metode pengisian kusioner dengan menggunakan pertanyaan yang di tetapkan.

\section{b) Perancangan Aplikasi}

1) Data Flow Diagram

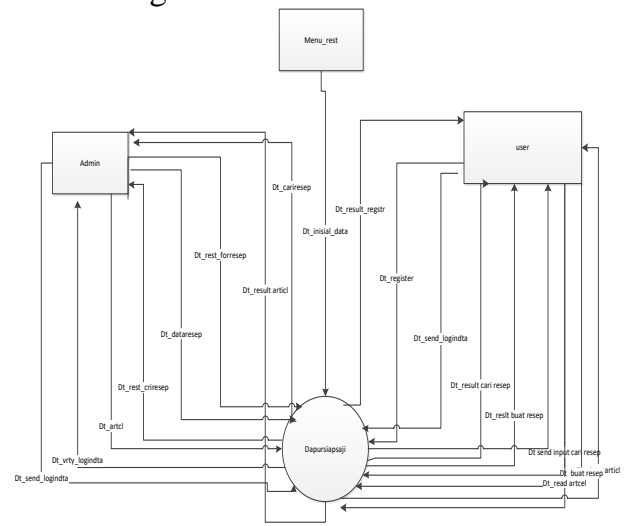

Gambar 3.contex diagram

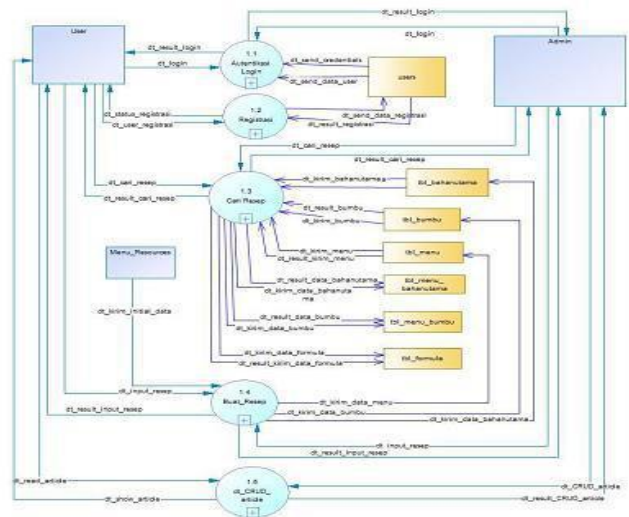

Gambar 4.dfd level 0

2) Flowchart

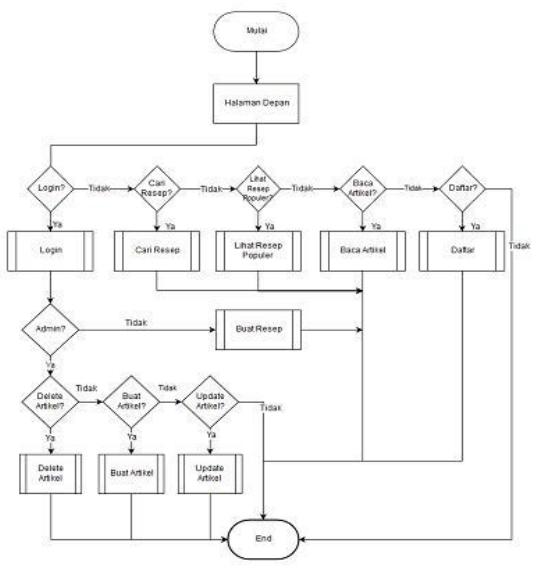

Gambar 5. Flowchart system

\section{Kesimpulan}

Disimpulkan bahwa rancang bangun telah berhasil dilakukan dengan menggunakan metode Collaborative Collective Intelligence dan Slope One 
berbasis web. Dengan tingkat kepuasan sebesar yang mungkin akan di dapatkan teman uji coba. Berdasarkan hasil penelitian, metode ini cukup efektif untuk memberikan rekomendasi item lainnya berdasarkan rating dari pengguna itu sendiri sehingga algoritmaini sangat cocok dipasangkan dengan metode Collaborative Collective Intelligence. Slope One memberi perhitungan dengan perbandinganratingrating dari beberapa item yang telah dilakukan oleh pengguna itu sendiri,maupun pengguna itu sendiri untuk kepuasan semua peminat.

\section{Terima Kasih}

Dengan ini penulis selaku peneliti mengucapkan banyan terima kasih untuk teman-teman yang sudah membantu dan saling member ide dalam pembuatan jurnal dengan aplikasi system ini semoga bermanfaat.

Terima kasih juga untuk Bapak Dosen Matakuliah yang sudah mengarahkan saya dalam format yang ada untuk pembuatan jurnal ini.

\section{Daftar Pustaka}

1. Wahlqvist, Mark L. 1999. Home Cooking Could Make You Live Longer. Diunduh Maret 2, 2016, dari

2. http://artsonline.monash.edu.au/mai/ home-cooking-makesyou-livelonger/

3. Tanu, Randi, 2015. Rancang Bangun Aplikasi Rekomendasi

4. Resep Masakan Menggunakan Metode Simple Additive

5. Weighting Berbasis Android. Skripsi UMN.

6. Modok,Mersi,2018. Aplikasi Rekomendasi Resep Masakan Khas Indonesia bagian Timur Menggunakan Metode Collaboration Collective Intelligence dan Slope One 